\title{
溶融 $\mathrm{Al}$ と黒鉛, $\mathrm{Al}_{2} \mathrm{O}_{3}, \mathrm{SiO}_{2}$ の濡れ性に及ぼす $\mathrm{Ca}$ の影響
}

\author{
森信幸* 空野博明** 北原 晃*** \\ 大城桂 作 ${ }^{*}$ 松田公扶*
}

J.Japan Inst.Metals, Vol.47,No.12(1983),pp.1132-1139

Effect of $\mathrm{Ca}$ on the Wettability of Liquid $\mathrm{Al}$ to Graphite, $\mathrm{Al}_{2} \mathrm{O}_{3}$ and $\mathrm{SiO}_{2}$
Nobuyuki Mori*, Hiroaki Sorano**, Akira Kitahara***, Keisaku Ōgi* and Kimio Matsuda*

The effect of $\mathrm{Ca}$ addition on the wettability and the interaction of liquid $\mathrm{Al}$ on graphite, $\mathrm{Al}_{2} \mathrm{O}_{3}$, and $\mathrm{SiO}_{2}$ substrates has been investigated in the atmosphere of low pressure $(0.27-0.67 \mathrm{kPa}) \mathrm{H}_{2}$ gas at temperatures over the range from $973 \mathrm{~K}$ to $1123 \mathrm{~K}$ by the sessile drop method.

Results obtained are as follows :

(1) The wetting angles between liquid $\mathrm{Al}$ and graphite, $\mathrm{Al}_{2} \mathrm{O}_{3}$ and $\mathrm{SiO}_{2}$ substrates show a tendency to decrease with $1-2 \% \mathrm{Ca}$ addition and increasing temperature.

(2) The wetting angles of liquid $\mathrm{Al}$ and $\mathrm{Al}-\mathrm{Ca}$ alloy on graphite substrates decreased with elapse of the wetting time at temperatures above $1123 \mathrm{~K}$. This phenomenon is more remarkable at higher temperatures, and is considered to be due to the formation of $\mathrm{Al}$ carbide at the interface.

(3) The wettability of $\mathrm{Al}_{2} \mathrm{O}_{3}$ substrate by liquid $\mathrm{Al}-\mathrm{Ca}$ alloy is almost unchanged by elapse of the wetting time and by the formation of $\mathrm{Ca}$ oxide at the interface.

(4) The wettability of $\mathrm{SiO}_{2}$ substrate by liquid $\mathrm{Al}$ has the time dependence, which is associated with the formation of significant amounts of interfacial compounds. On the other hand, by liquid Al-Ca alloy the wettability does not have the time dependence, and the formation of compounds is decreased with addition of $\mathrm{Ca}$.

(Received April 15, 1983)

Keywords : casting composite, wettability, contact angle, aluminum-calcium alloy, ceramics, graphite, interfacial reaction

\footnotetext{
* 九州大学工学部 (Faculty of Engineering, Kyushu University, Fukuoka)

** 九州大学大学院生, 現在 : 日立金属株式会社若松工場 (Graduate Student, Kyushu University, Fukuoka. Present address : Wakamatsu Factory, Hitachi Metals Ltd., Kitakyushu)

*** 九州工業技術試験所 (Government Industrial Research Institute, Kyushu, Tosu)
} 


\section{I. 緒言}

溶融金属中にセラミックス等の粒子を機械的擋拌により 分散させて複合材料を製造する，いわゆるボルテックス法 等においては, 溶融金属と添加材の接触により生じる問題 として両者間の濡れ性や界面反応がある。一般に接触角の 小さい系活ど固体と液体の間の接触面が大きくなるため複 合化が安定かつ容易に行われ，また界面反応は材料特性に 影響するため，これらは複合材料製造上の基本的問題であ る.

従来より純 $\mathrm{A} 1$ に関しては種々の固体基盤について濡れ 性に及ぼす温度や接触時間の影響などが詳細に研究されて おり，また合金元素添加時の需れに関しても実験されてい るが(1)-(10), 溶融 $\mathrm{A} 1$ への酸化物や黒鉛粒子の分散促進作 用の認められている $\mathrm{Ca}{ }^{(11)}$ の添加に関する研究はほとんど 行われていない。これは $\mathrm{A} 1-\mathrm{Ca}$ 融液が非常に酸化されや すく, しかも Ca の蒸気圧が高いため, 䨌囲気調整が 困難 なためと考兄られ, 本研究の予備実験でも通常の高真空 $1 \mathrm{mPa}$ ( 10 $0^{-5}$ Torr) や $\mathrm{H}_{2}$ ガス雾囲気では Ca の蒸発や表 面酸化皮膜の影響が除去できず，実験不可能であった.

そこで，本研究では，まず以上の問題点を解決するた め, 精製した $\mathrm{H}_{2}$ ガスをスポンジ Ti に吸蔵させ，これを 真空ポンプで吸引して減圧 $\mathrm{H}_{2}$ ガス雲囲気を作り，この中 で液滴を基盤上に押し出して静滴法により接触角を測定す る方法を開発した。 そしてこの方法により，純 $\mathrm{A} 1$ および $\mathrm{Al}-\mathrm{Ca}$ 合金液滴と黒鉛, $\mathrm{Al}_{2} \mathrm{O}_{3}$ 打よび $\mathrm{SiO}_{2}$ との濡れ性お よび反応性を $973 \mathrm{~K} \sim 1273 \mathrm{~K}$ の温度で 0 ～3.6 ks にわたっ て測定した。

\section{II. 実 験 方 法}

\section{1. 実験試料}

液滴用金属は，高純度 $\mathrm{Al}(99.99 \%)$ と $\mathrm{Ca}(99 \%)$ を原料 として溶製した純 $\mathrm{A} 1, \mathrm{~A} 1-1 \% \mathrm{Ca}$ 扎よび $2 \% \mathrm{Ca}$ 合金を用い た。これらの合金は外径 $5 \mathrm{~mm}$ の棒状に鋳造し，旋盤で外 径 $4.7 \mathrm{~mm}$ にした後切断して約 $0.24 \mathrm{~g}$ の試片とした。実 験に用いた合金の分析值は $1.1 \% \mathrm{Ca}$ および $2.2 \% \mathrm{Ca}$ であった。

固体基盤としては，市販の透光性 $\mathrm{Al}_{2} \mathrm{O}_{3}\left(99.9 \% \mathrm{Al}_{2} \mathrm{O}_{3}\right)$ ，透明 $\mathrm{SiO}_{2}$ ガラ

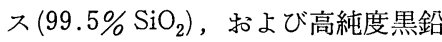
焼結体 $(99.85 \% \mathrm{C}, 0.05 \%$ 灰分)を， $20 \mathrm{~mm} \times 20 \mathrm{~mm} \times 3 \mathrm{~mm}$ の板状試料 として表面を鏡面仕上げしたものを 用いた。これらの基盤はアセトン で超音波洗浄後, $1.3 \times 10^{-4} \mathrm{~Pa}\left(10^{-6}\right.$. Torr), $1273 \mathrm{~K}$ で $1.8 \mathrm{ks}$ 間空焼きし て実験に供した。

\section{2. 実験装置および操作}

$\mathrm{A} 1-\mathrm{Ca}$ 合金では $\mathrm{Ca}$ の蒸気圧が高いため, 高真空では $\mathrm{Ca}$ の蒸発減少が著しく，また $\mathrm{A} 1, \mathrm{Ca}$ とも非常に酸化しや すく液滴表面に酸化皮膜を作りやすい，Ca の蒸発を防ぎ， かつ清浄な表面をもつ液滴を作るため, 以下に述べるよう に䨌囲気拉よび液滴形成法に特別の工夫をした。

Fig. 1 に実験装置の概略図, Fig. 2 飞液滴滴下装置を示 す。液滴用試料 (約 $0.24 \mathrm{~g}$ ) は内径 $5 \mathrm{~mm}$ の黒鉛シリンダー に入れて基盤とともに液滴滴下装置に入れ，これを Fig.1 の試料室内の均熱部に基盤が水平になるように置いた。 た，試料室に連続した $\mathrm{H}_{2}$ ガス吸蔵用 $\mathrm{Ti}$ 炉内には $\mathrm{Ti}$ スポ ソジを入れた

実験は，まず試料室およびガス中の不純物除去用の Ti 炉と $\mathrm{Mg}$ 炉を約 $1.3 \times 10^{-2} \mathrm{~Pa}\left(10^{-4} \mathrm{~T}\right.$ orr $)$ まで真空排気し た後，試料を $793 〜 803 \mathrm{~K}$ に昇温して $1.8 \mathrm{ks}$ 間保持して脱 ガスし, 同時に $\mathrm{H}_{2}$ ガス吸蔵用 $\mathrm{Ti}$ 炬は $973 \mathrm{~K}$ に加熱した. 次いで， $\mathrm{H}_{2}$ ガスを $853 \mathrm{~K}$ に保持した $\mathrm{Mg}$ 炉特よび $1073 \mathrm{~K}$ の $\mathrm{Ti}$ 炉を通し，さらに液体トラップを通して酸素, 窒素, 水分等の不純物を十分除去 (酸素分圧 $\lesssim 10^{-15} \mathrm{~Pa}$ ) した後, 吸蔵 Ti 炉へ供給して $\mathrm{Ti}$ に $\mathrm{H}_{2}$ を吸蔵させた. $3.3 \mathrm{~cm}^{3} / \mathrm{s}$ の $\mathrm{H}_{2}$ 気流中で試料を $973 \sim 1273 \mathrm{~K}$ の測定温度まで昇温し た後, 吸蔵 $\mathrm{Ti}$ 炉と試料室を真空吸引することにより， Ti 中の吸蔵 $\mathrm{H}_{2}$ を放出させた. $\mathrm{H}_{2}$ ガス雾囲気圧力が 0.67 $\mathrm{kPa}$ (5 Torr) になったときに, 液滴滴下装置を作動させて 固体基盤上に液滴を静かに滴下させ，滴下直後から $300 \mathrm{~s}$ 毎に $3.6 \mathrm{ks} に わ た り$ 液滴を写真撮影した。なお，この液 滴滴下法は，固体金属片を最初から基盤上に置いて拈く方 法に比べて，任意の測定温度で液滴と基盤との接触を開始 できる上，初めに存在した表面酸化皮膜を破って滴下させ るため表面の清浄な液滴を形成できる利点がある。また， Ca の蒸発や酸化の影響を受けない条件として, $0.27 〜 0.67$ $\mathrm{kPa}(2 \sim 5$ Torr $)$ の $\mathrm{H}_{2}$ ガス圧が必要であったため, Tiへの $\mathrm{H}$ 溶解度が高温ほど小さい(12)ことを利用し，測定中に $\mathrm{H}_{2}$ 吸蔵用 Ti 炉の温度を $3.6 \mathrm{ks}$ で約 $200 \mathrm{~K}$ 段階的に昇温さ せて,この $\mathrm{H}_{2}$ ガス圧を維持した。この結果, Table 1 に

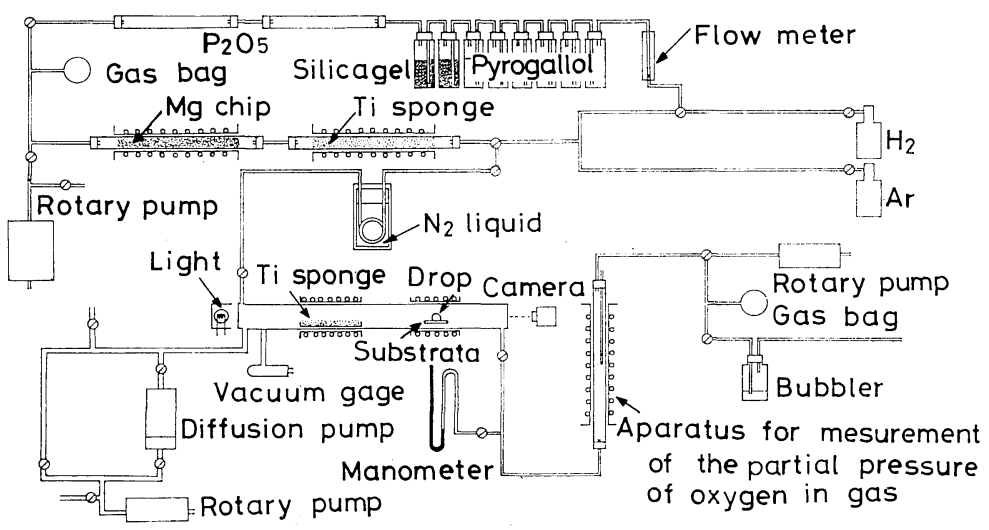

Fig.1 Apparatus for measurements of wettability. 


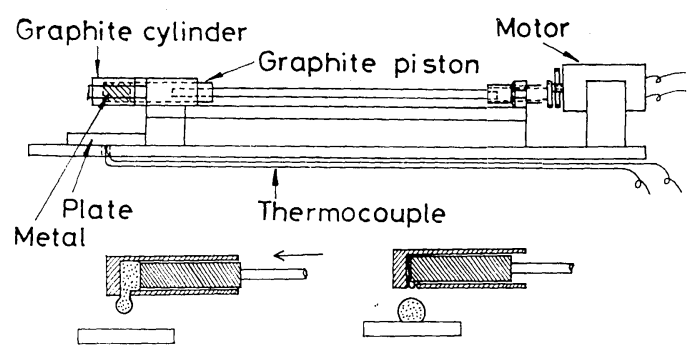

Fig.2 Metal dropping apparatus.

Table 1 Variation of $\mathrm{Ca}$ content in $\mathrm{A} 1-2 \% \mathrm{Ca}$ alloys after holding at $1173 \mathrm{~K}$ in vacuum or low pressure $\mathrm{H}_{2}$ gas atmosphere.

\begin{tabular}{c|c|c|c}
\hline $\begin{array}{c}\text { Initial } \\
\text { composition }\end{array}$ & $\begin{array}{c}\text { Pressure } \\
(\mathrm{Pa})\end{array}$ & $\begin{array}{c}\text { Holding } \\
\text { time }(\mathrm{s})\end{array}$ & $\begin{array}{c}\mathrm{Ca} \\
(\%)\end{array}$ \\
\hline & & 0 & 2.10 \\
& $5.3 \times 10^{-3}$ & 1800 & 1.33 \\
$\mathrm{~A} 1-2.2 \% \mathrm{Ca}$ & & 3600 & 0.76 \\
\cline { 2 - 4 } & & 0 & 2.20 \\
& $(0.27 \sim 0.67)$ & 1800 & 2.05 \\
& $\times 10^{3}\left(\mathrm{H}_{2}\right)$ & 3600 & 1.90 \\
\hline
\end{tabular}

示した真空 $5.3 \mathrm{mPa}\left(4 \times 10^{-5}\right.$ Torr $)$ および減圧 $\mathrm{H}_{2}$ 雾用気 $0.27 \sim 0.67 \mathrm{kPa}(2 \sim 5$ Torr $)$ 中で $1173 \mathrm{~K}$ で $0,1.8 \mathrm{ks}$ 扰よ び $3.6 \mathrm{ks}$ 保持した後に急冷した液滴の Ca 分析値の例のよ らに，真空中では保持時間の増加とともに著しく Ca 量が 減少したが，減圧 $\mathrm{H}_{2}$ 雲囲気中では減少 量を小さくするこ とができた，この $\mathrm{Ca}$ 減少量をさらに小さくするため， $\mathrm{H}_{2}$ ガス圧を上げると表面酸化皮膜の影響のためか液滴の滴下 が困難であったため，本実験では上記の範囲の $\mathrm{Ca}$ 変化量 は無視できるとして，0.27〜0.67 kPa (2〜5 Torr)の $\mathrm{H}_{2}$ ガ ス雲囲気で実験した。

接触角の撮影が終了した試料は割型炉を取り外すことに より急冷し，界面反応層観察用試料とした。

接触角の測定はすべての試料について 973,1073 および $1173 \mathrm{~K}$ で行い，純 $\mathrm{A} 1$ については $1273 \mathrm{~K}$ でも測定した。 また接触角の時間変化に規則性の認められる黒鉛基盤につ いては,特に $1123,1223 \mathrm{~K}$ での測定も行った. 接触角 $\theta$ は, 液滴の形状を球の一部とみなして液滴の高さ $(h)$ と接触部 の幅 $(2 x)$ を写真フィルムより測定し, $\theta=2 \tan ^{-1}(h / x) よ り$ 求めた。

\section{III. 実験結果および考察}

\section{1. 黒鉛と溶融 $\mathbf{A} 1$ および Al-Ca 合金のぬれ性}

Fig.3 (a) 〜 (c) 飞，黒鉛基盤に対する $\mathrm{Al}, \mathrm{Al}-1 \% \mathrm{Ca}$ 特 よび $2 \% \mathrm{Ca}$ 合金液滴の接触角 $\theta$ と時間 $t$ の関係を示す. いずれの場合も保持温度が $973 \mathrm{~K}$ では $\theta$ は時間に対しほ とんど変化しない. しかし $1073 \mathrm{~K}$ 以上になると $\theta$ は時間 経過とともに減少する傾向が認められ, $1123 \mathrm{~K}$ 以上でこの 傾向は顕著になり，かつ高温汪ど $\theta$ の値は小さくなってい る。ただし，Al-Ca 合金では高温になると表面に酸化皮膜

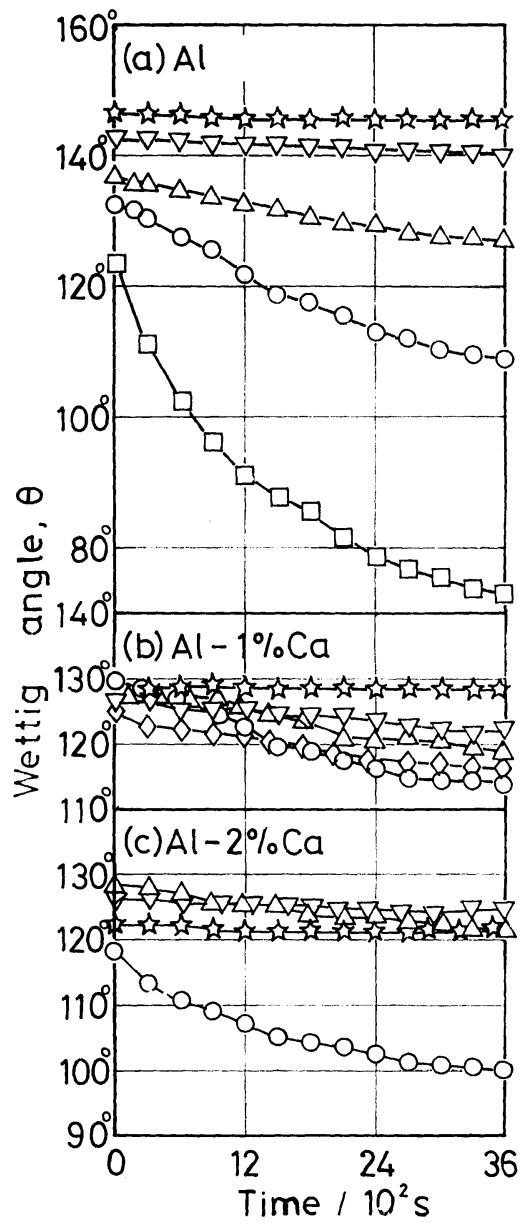

今 $973 \mathrm{~K}, \nabla 1073 \mathrm{~K}, \triangle 1123 \mathrm{~K}$

O 1173K, $\diamond 1223 \mathrm{~K}, \square 1273 \mathrm{~K}$

Fig. 3 Wetting angle vs time for $\mathrm{Al}$ (a), $\mathrm{Al}-1 \% \mathrm{Ca}$ (b), and $2 \% \mathrm{Ca}$ (c) alloy on graphite at various temperature.

が生成するためか，液滴を基盤上へ滴下させることが困難 となり，1\%Ca 合金では $1223 \mathrm{~K}, 2 \% \mathrm{Ca}$ 合金では $1173 \mathrm{~K}$ までの測定が限度であった。

このような時間経過に伴う $\theta$ の変化は液滴と黒鉛の界面 反応が原因ではないかと考えられる，そこで Fig.4に黒 鉛基盤と $\mathrm{Al}$ 液滴を $1273 \mathrm{~K}$ で $3.6 \mathrm{ks}$ 保持した後の界面組 織を示す。(a)は界面中央部，(b)は端部に近い所で，写真 の下側が黒鉛，上側が Al で，その間に反応層が認められ る. 界面中央部の反応層が約 $15 \mu \mathrm{m}$ 程度で厚く，端部では 薄く不連続になっているのは，液滴が時間とともに基盤上 に拡がることから端部の方が接触時間が短いためと考えら れ，ぬれの進行は界面反応層の生成と対応づけられる。な 招, 反応層の EPMA 分析により Al とCが検出されたこ とから生成物は $\mathrm{Al}$ 炭化物 $\left(\mathrm{Al}_{4} \mathrm{C}_{3}\right)$ と考兵られるが，Cの定 量は難しく，またこれは加水分解し易いため ${ }^{(13)}$ ，その同 定は困難であった。このような反応層は $1173 \mathrm{~K}$ で $3.6 \mathrm{ks}$ 
保持の場合にはより薄く $(3 \sim 5 \mu \mathrm{m})$ かつ不連続になり，さ らに $1073 \mathrm{~K}$ 以下では存在を確認できなかった。従って, 黒鉛基盤- $\mathrm{Al}$ 系では高温ほど界面反応が著しいため接触角 の変化も大きいと考光られる。な拉， $\mathrm{Al}$ 融液への C 溶解 度はほ㟫ゼロであり ${ }^{(14)}$, 反応による液滴組成の変化はな いと考光られる。

A1-Ca 合金の場合には, $973 \mathrm{~K}$ および $1073 \mathrm{~K}$ でも厚さ 2 3 3 m の不連続な界面反応層が生成し, $1073 \mathrm{~K}$ の方が その連続性が増大したが, $1173 \mathrm{~K}$ ではむしろ薄くなり， 反応層の厚さと温度には純 $\mathrm{A} 1$ のように単純な相関関係が 認められない。これは, 生成した炭化物が不連続で融液中 に遊離するためではないかと考えられるが，Ca 炭化物は Al 炭化物と同様に加水分解してしまうためこれらの微小 な化合物の同定も困難であり，詳細は不明である。

次に, 接触角 $\theta$ を温度との関係として Fig.5 に示す. 図中の黒印 $(\bullet, \Delta, \diamond)$ は保持時間 $300 \mathrm{~s}$ での值, 白印 $(O$,

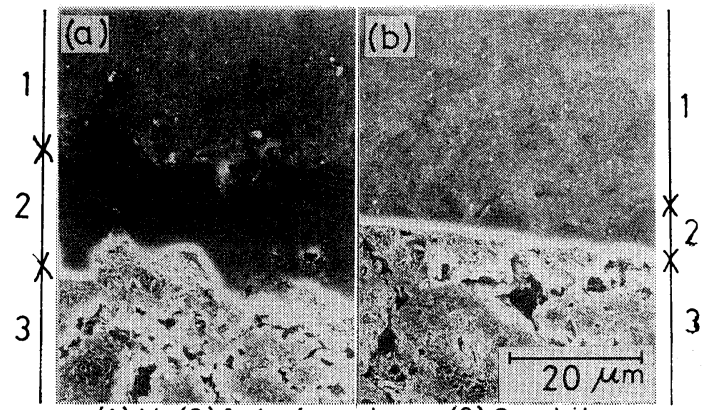

(1)Al, (2) In tertace layer, (3) Graphite

Fig. 4 Cross sections of interfaces between $\mathrm{Al}$ and graphite held at $1273 \mathrm{~K}$ for $3.6 \mathrm{ks}$.

(a) central part, (b) end part

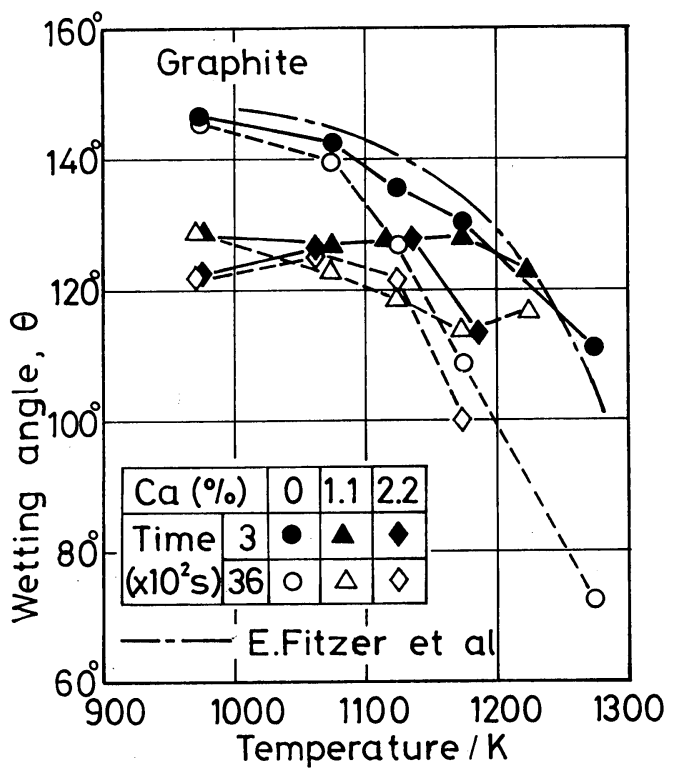

Fig. 5 Wetting angle vs temperature for $\mathrm{Al}$ and Al-Ca alloys on graphite. (Wetting time : $300 \mathrm{~s}$ and $3.6 \mathrm{ks})$
$\Delta, \diamond)$ は $3.6 \mathrm{ks}$ 保持後の值である. $300 \mathrm{~s}$ 保持後の $\theta$ は, 純 $\mathrm{A} 1$ 液滴の場合(の) には高温ほど值が小さくなっており, 従来公表されている $300 \mathrm{~s}$ 保持後の測定結果 (図中の一点 鎖線 $\left.{ }^{(2)}\right)$ とよく一致している.しかし Ca を含む場合には， 低温では純 $\mathrm{A} 1$ より著しく $\theta$ が小さいが， $\theta$ の温度による 変化が流とんどないため, 高温では純 $\mathrm{Al}$ との差が小さく なる.これに対し， $3.6 \mathrm{ks}$ 保持後の $\theta$ は, 純 $\mathrm{A} 1, \mathrm{Al}-\mathrm{Ca}$ 合金のいずれも高温ほど小さくなって扣り，その程度は純 A1 で著しい。

$\theta$ に及ぼすCa の影響について Fig.6 に示す。図中の黒 印は $300 \mathrm{~s}$ 保持, 白印は $3.6 \mathrm{ks}$ 保持後の值である. $300 \mathrm{~s}$ 保持後の $\theta$ はいずれの温度でも Ca 量が多い注ど值が小さ く, Ca はぬれ性を改善する効果が認められる。 $3.6 \mathrm{ks}$ 保 持後の $\theta$ む $1073 \mathrm{~K}$ 以下では Caによるぬれ促進効果が認 められるが, $1173 \mathrm{~K}$ では $1 \% \mathrm{Ca}$ の場合より純 $\mathrm{A} 1$ の方が $\theta$ はむしろ小さくなっている。これは, 前述のように $\mathrm{Ca}$ の添加により高温での界面反応層の生成が抑制されるため である。

ところで，既に Fig.3 に示したように黒鉛基盤では純 A1 および A1-Ca 合金のいずれについても，1073〜1173 K 以上の高温になると接触角は時間に対して単調に減少し た。このような接触角の時間変化については次の Neuman の式が提案されている(15)(16).

$$
\cos \theta=\left(\cos \theta_{\infty}\right)\{1-a \exp (-b t)\}
$$

この式で， $\theta_{\infty}$ は平衡接触角であるが，前述のように本 実験では水素ガス圧力を $0.27 〜 0.67 \mathrm{kPa}(2 \sim 5$ Torr) の範 用内に維持するための制限条件から，時間 $t=3.6 \mathrm{ks}$ まで の測定しか行えなかったため， $\theta$ は未だ減少する傾向を残 しており厳密な $\theta_{\infty}$ は求めることはできない.そこで，こ
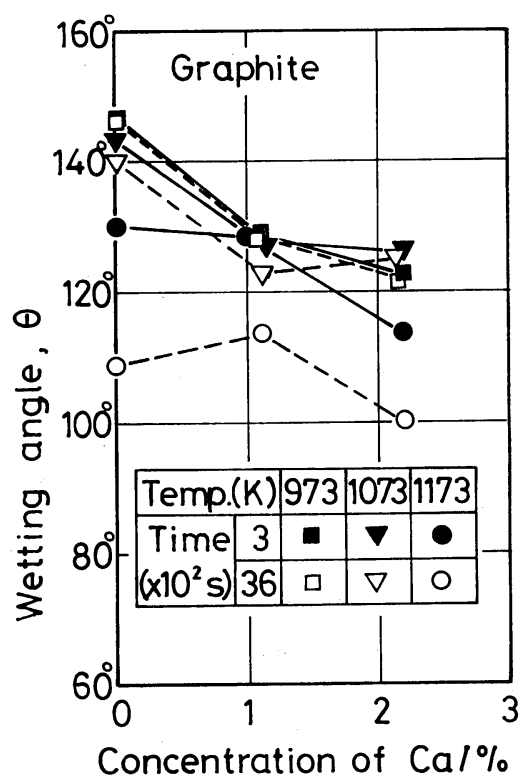

Fig.6 Wetting angle vs $\mathrm{Ca}$ content for $\mathrm{Al}$ and $\mathrm{Al}$ $\mathrm{Ca}$ alloys on graphite. (Wetting time :300 s and $3.6 \mathrm{ks}$ ) 


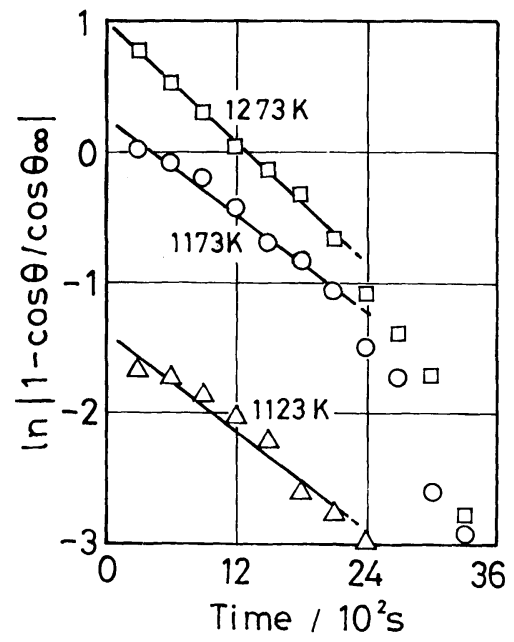

Fig.7 Time dependence of $\ln \left|1-\cos \theta / \cos \theta_{\infty}\right|$ for $\mathrm{Al}$ on graphite at $1123 \mathrm{~K}, 1173 \mathrm{~K}$ and $1273 \mathrm{~K}$.

こでは $t=3.6 \mathrm{ks}$ での $\theta$ 值を $\theta_{\infty}$ の近似值として仮定し, 比較的 $t$ の小さい間のぬれの変化について検討してみた.

Fig.7 は, 純 $\mathrm{A} 1$ の場合の $\ln \left|1-\cos \theta / \cos \theta_{\infty}\right|$ と時間 $t$ の関係である。保持時間が約 $2 \mathrm{ks}$ 位までは注淔線関係 が成立し，その勾配は高温ほど急になっている。な㧺図中 の直線は $t=300 \mathrm{~s} \sim 2.1 \mathrm{ks}$ 間のデータから最小 2 乗法によ り求めた。これらの状態ではぬれの進行は液滴と基盤の界 面反応の進行に対応するのであろら。また，Al-Ca 合金で も同様の直線関係が成立し，やはり界面反応によりぬれが 促進されたと考えられる。な特，ここで式 (1)の定数bは ぬれの速度定数と考兄られ, $b$ 温度依存性から Arrhenius の式により活性化エネルギーを求めることもできるが(15)， 本実験では厳密な $\theta_{\infty}$ の値が不明なため，正確な $b$ の値を 得ることができなかった。

\section{2. $\mathrm{Al}_{2} \mathrm{O}_{3}$ および $\mathrm{SiO}_{2}$ と溶融 $\mathrm{Al}, \mathrm{Al}-\mathrm{Ca}$ 合金の ぬれ性}

Fig.8 (a)〜 (c) は， $\mathrm{Al}_{2} \mathrm{O}_{3}$ 基盤に対する溶融 $\mathrm{Al}, \mathrm{Al}-1 \%$ $\mathrm{Ca}$ 扎よび $2 \% \mathrm{Ca}$ 合金の接触角 $\theta$ と時間 $t$ の関係である。 いずれの $\mathrm{Ca}$ 濃度の場合にも $\theta$ は高温ほど小さいが, 1173 $\mathrm{K}$ 以下では $\theta$ の経時変化は全く認められず, 純 $\mathrm{A} 1$ の 1273 $\mathrm{K}$ の場合のみ接触時間の増加とともに $\theta$ が減少している.

純 $\mathrm{A} 1-\mathrm{Al}_{2} \mathrm{O}_{3}$ 系の接触角については従来より多くの研究 があり，一般に接触角は接触開始後少なくとも 10 分〜数 10 分間は減少するとされている(7)-(10). これに対し，本 実験の測定值は最初からほぼ一定值で変化がほとんど認め られない，この原因は，従来の研究では基盤上に固体金属 を乗せておいて加熱し液滴を形成させる方法であるため， 初期の非平衡接触の状態が顕著に現われるためではないか と考觉られる。

Fig.9(a)〜 (c) は， $\mathrm{SiO}_{2}$ 基盤に対する $\theta$ の測定結果であ る.純 $\mathrm{Al}$ では $1073 \mathrm{~K}$ 以上では $\theta$ は時間とともに減少する 傾向が認められるが, $\mathrm{Al}-\mathrm{Ca}$ 合金では $\theta$ の経時変化は注

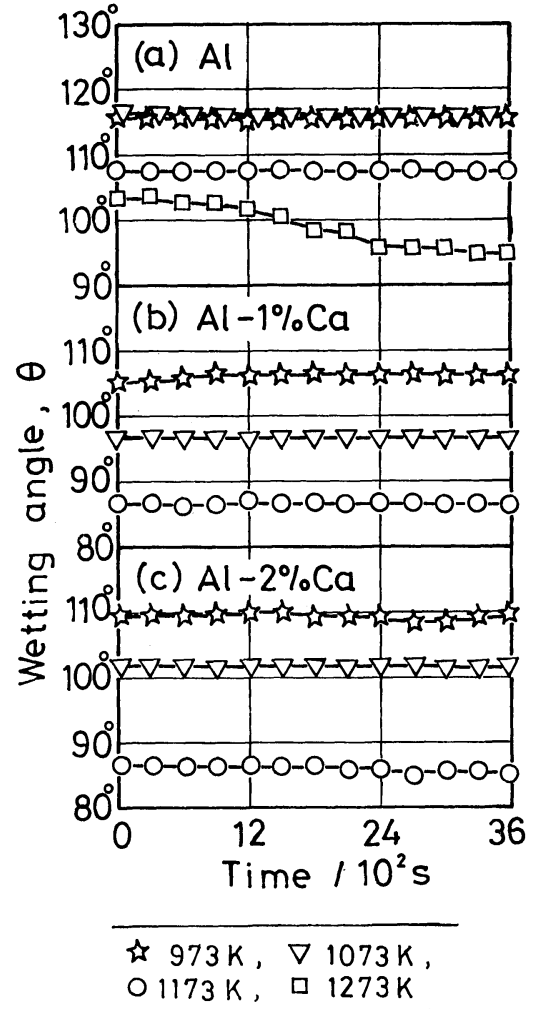

Fig. 8 Wetting angle vs time for $\mathrm{Al}$ (a), $\mathrm{Al}-1 \% \mathrm{Ca}$ (b), and $2 \% \mathrm{Ca}$ (c) alloy on $\mathrm{Al}_{2} \mathrm{O}_{3}$ at various temperature.

とんどない，なお，1173 K 以下ではいずれの試料も高温 ほど $\theta$ は小さいが，純 $\mathrm{A} 1$ の $1273 \mathrm{~K}$ では $1173 \mathrm{~K}$ より $\theta$ の 値が大きいのは界面反応層が低温とは異なるためであろ 5 .

次に, 接触角 $\theta$ に及ぼす温度の影響を $\mathrm{Al}_{2} \mathrm{O}_{3}$ および $\mathrm{SiO}_{2}$ の基盤別に Fig.10(a)，(b)に示す. $300 \mathrm{~s}$ 保持後の $\theta$ (•, $\Delta, \diamond)$ は，いずれの基盤も温度が高い注ど小さくなる傾向 があるが，黑鉛基盤の場合とは逆に，純 $\mathrm{Al}$ よりも $\mathrm{Al}-\mathrm{Ca}$ 合金で $\theta$ の温度による変化が大きい傾向である. $3.6 \mathrm{ks}$ 保 持後の場合には，いずれの基盤とも純 $\mathrm{Al}$ では温度増加に 伴う $\theta$ の減少程度が $300 \mathrm{~s}$ 保持の場合より大きいが，A1$\mathrm{Ca}$ 合金では $300 \mathrm{~s}$ 保持の場合とほぼ同じである.

Fig.10(a)の一点鎖線 ${ }^{(7)}$ 怔よび二点鎖線 ${ }^{(6)}$ は, 純 $\mathrm{A} 1$ と $\mathrm{Al}_{2} \mathrm{O}_{3}$ との接触角の温度依存性を示した文献值である。研 究者により測定値はかなり異なっているが，本研究の測定 值は注ぼこれらの文献值の中間の值である。また同図 (b) の一点鎖線は, $\mathrm{SiO}_{2}$ 基盤と純 $\mathrm{A} 1$ の接触角の文献値 ${ }^{(6)}$ であ り，本実験結果より温度依存性が大きいが，1023 K 前後 での值は近い.

Fig.11に $\theta$ に及ぼす $\mathrm{Ca}$ 濃度の影響を示す. $\mathrm{Al}_{2} \mathrm{O}_{3}$ およ び $\mathrm{SiO}_{2}$ のいずれの基盤についても $\mathrm{Ca}$ は保持温度，時間 によらず $\theta$ を減少させ，黒鉛の場合と同様にぬれ性の改善 効果がある．特に， $1173 \mathrm{~K}$ ではいずれの基盤とも $\mathrm{Ca}$ 添加 
により $\theta \lesssim 90^{\circ}$ となり，ぬれの増加が著しい。しかし $\mathrm{Al}_{2} \mathrm{O}_{3}$ 基盤では $\mathrm{Ca}$ 添加量が $1 \%$ と $2 \%$ でほとんど差がなく, Ca によるぬれ性改善効果には制限がある.

Fig. 12 は， $\mathrm{Al}_{2} \mathrm{O}_{3}$ 基盤上に $\mathrm{Al}-2 \% \mathrm{Ca}$ 合金液滴を 1173 $\mathrm{K}$ で $3.6 \mathrm{ks}$ 保持した後の界面部を EPMA で分析した結果 である，界面には Ca を含む約 $1.5 \mu \mathrm{m}$ の厚さの反応層が

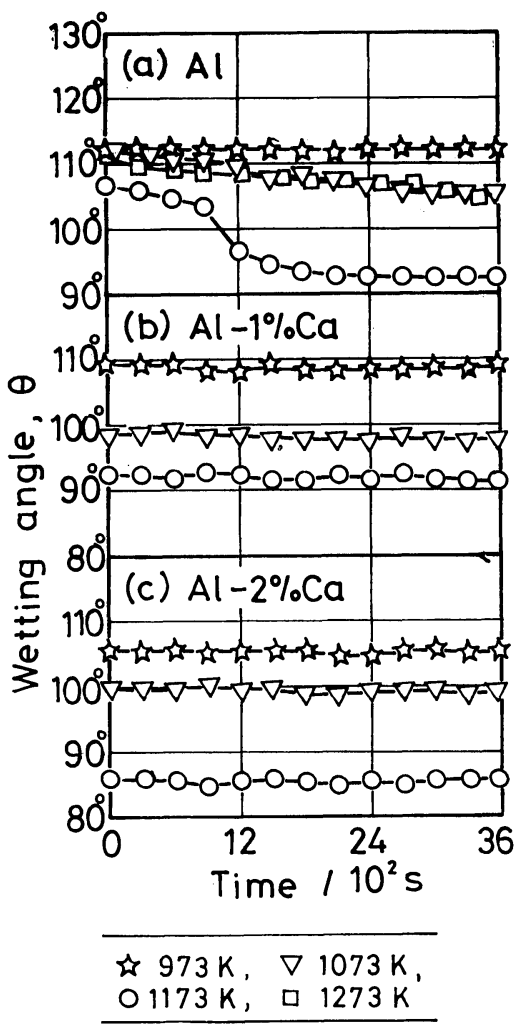

Fig. 9 Wetting angle vs time for $\mathrm{Al}$ (a), $\mathrm{Al}-1 \% \mathrm{Ca}$ (b), and $2 \% \mathrm{Ca}$ (c) alloy on $\mathrm{SiO}_{2}$ at various temperature.
認められ， $\mathrm{Al}_{2} \mathrm{O}_{3}$ が Ca により還元されて Ca 酸化物が生 成している。このような $\mathrm{Ca}$ を含む反応層は，Al-Ca 合金 液滴を $1073 \mathrm{~K}$ 以上で保持した場合に認められたが，どの 場合も接触角の経時変化はなく, 界面反応層は黒鉛基盤の 場合と異なりぬれの進行を促進しないといえる。

Fig. 13 は, $\mathrm{SiO}_{2}$ 基盤と $\mathrm{Al}$ 液滴を $1173 \mathrm{~K}$ で $3.6 \mathrm{ks}$ 保 持した後の界面反応層の組織と EPMA 分析 結果である. 反応層は厚さが約 $1500 \mu \mathrm{m}$ あり, その構造は複雑で, 液 滴との界面近傍は $\mathrm{A} 1$ を約 $50 \%$ 含み $\mathrm{Si}$ をとんど含まな い $\mathrm{Al}_{2} \mathrm{O}_{3}$ 層からなり，内部には $\mathrm{Si}$ を局所的に含む(写真中 白色部) $\mathrm{A} 1$ 酸化物層, および極めて微細な孔を含む領域 (I 2〜I3，I4〜I5 間)などからなっている. また，写真中 $\mathrm{I} 1$ より右側の $\mathrm{Al}$ 液滴中には板状の初晶 $\mathrm{Si}$ が認められ, 還元されて生じた Si が Al 中に多量に溶解したことを示 している. 反応層の厚さは $973 \mathrm{~K}$ では約 $100 \mu \mathrm{m}$ 以下であ るが, $1073 \mathrm{~K}$ では $1300 \mu \mathrm{m}, 1173 \mathrm{~K}$ では $1500 \mu \mathrm{m}$ と厚く

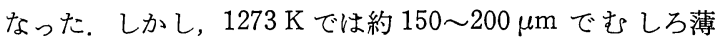

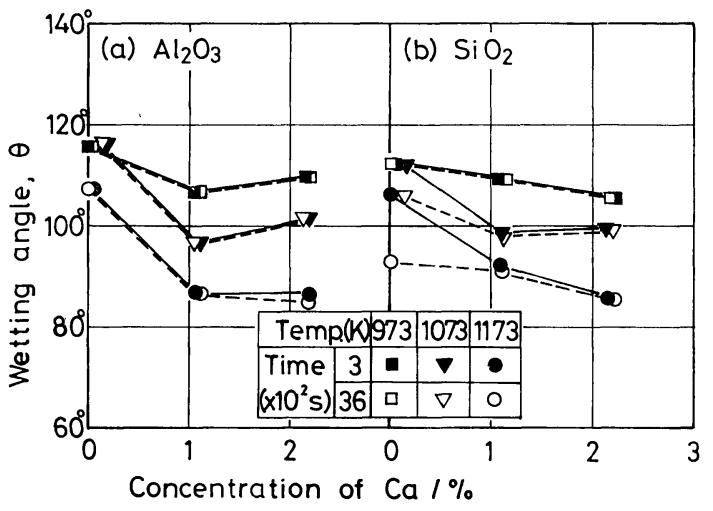

Fig. 11 Wetting angle vs $\mathrm{Ca}$ content for $\mathrm{A} 1-\mathrm{Ca}$ alloys on $\mathrm{Al}_{2} \mathrm{O}_{3}$ (a), and $\mathrm{SiO}_{2}$ (b) .

(Wetting time : $300 \mathrm{~s}$ and $3.6 \mathrm{ks}$ )

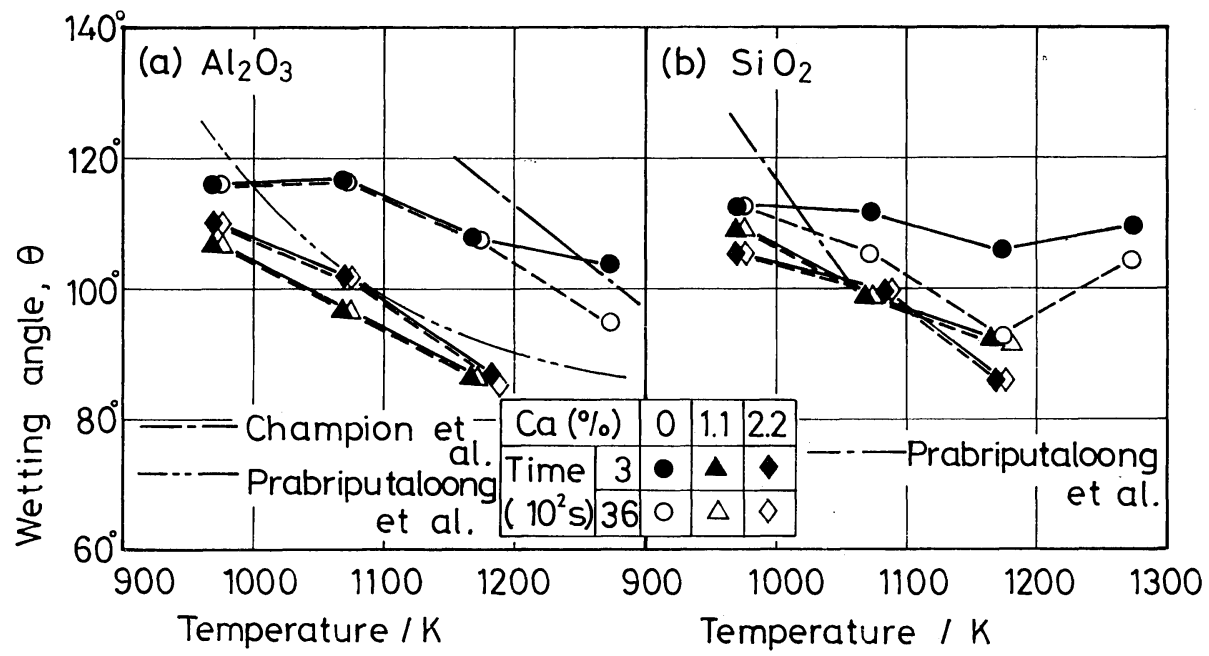

Fig.10 Wetting angle vs temperature for $\mathrm{Al}$ and $\mathrm{Al}-\mathrm{Ca}$ alloys on $\mathrm{Al}_{2} \mathrm{O}_{3}$ (a), and $\mathrm{SiO}_{2}$ (b). (Wetting time : $300 \mathrm{~s}$ and $3.6 \mathrm{ks}$ ) 
くなった。この原因として，約 $1273 \mathrm{~K}$ 以上の高温になる と還元生成物である $\mathrm{Al}_{2} \mathrm{O}_{3}$ と $\mathrm{SiO}_{2}$ 基盤が反応して緻密な ムライト層を形成する, あるいは $\mathrm{SiO}_{2}$ ガラスの結晶化が 起こり始めるなどにより，Al，Si イオンの拡散や界面化学 反応が遅くなることが考えられるが，詳細は不明である．

これに対して，Ca を含む晹合には反応層の生成が抑制 され， $\mathrm{A} 1-1 \% \mathrm{Ca}, 2 \% \mathrm{Ca}$ 合金とも $973 \mathrm{~K}$ では反応層は認め られず, $1073 \mathrm{~K}$ で 100〜 $500 \mu \mathrm{m}$ 厚さの不均一な反応層,

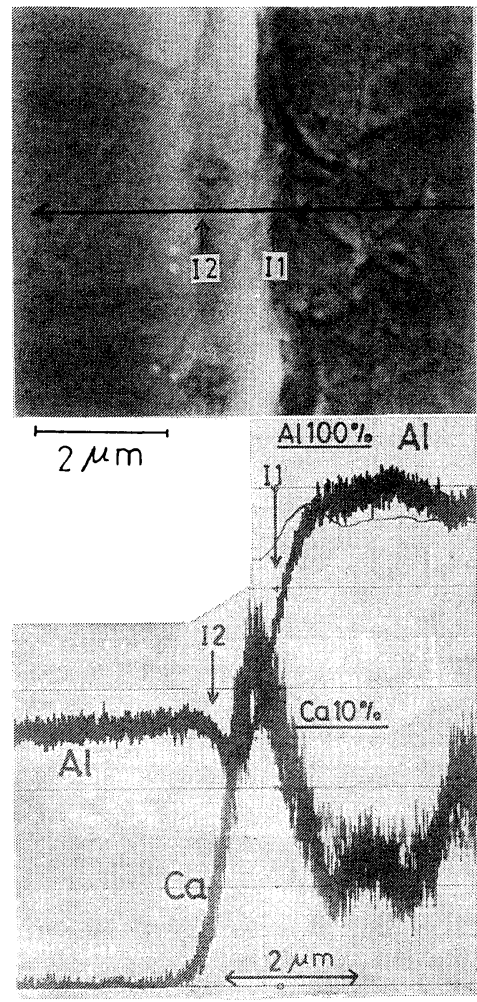

Fig.12 EPMA line-scanning profile across Al-Ca/ $\mathrm{Al}_{2} \mathrm{O}_{3}$ interface. Specimen was held at $1173 \mathrm{~K}$ for $3.6 \mathrm{ks}$ prior to the analysis.

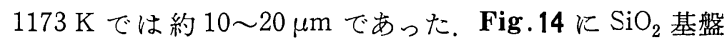
と $\mathrm{A} 1-1 \% \mathrm{Ca}$ 合金液滴を $1173 \mathrm{~K} \mathrm{~V} 3.6 \mathrm{ks}$ 保持した後の界 面反応層を EPMA 分所した例を示す. 反応層は 2 層から なって扣り，界面に接して $\mathrm{Ca}$ と $\mathrm{Al}$ の酸化物からなる $\mathrm{Si}$ をほとんど含まない第 1 層があり，続いて Ca を含まず一 部 $\mathrm{Si}$ が残羿した $\mathrm{A} 1$ 酸化物層がある。 $\mathrm{A} 1-\mathrm{Ca}$ 合金では $1073 \mathrm{~K}$ 以上でこの例のように界面に接して Ca に富む酸化 物層が認められた。酸素との親和力が $\mathrm{Al}$ より大きい $\mathrm{Ca}$ が存在する場合には $\mathrm{Ca}$ の酸化物が優先して形成され, こ の $\mathrm{Ca}$ を含む第 1 反応層が安定で $\mathrm{Al}_{\mathrm{z}} \mathrm{O}_{3}$ 層への $\mathrm{Al}$ の拡散 や $\mathrm{Al}$ 液滴への $\mathrm{Si}$ の拡散を妨害するため, 第 2 層の成長 が抑制されるのではないかと考えられる。

以上のように, $\mathrm{SiO}_{2}$ 基盤は溶融 $\mathrm{Al}$ によって迺元され， 著しい界面反応層を生じるとともに, $\mathrm{A} 1$ 中へ $\mathrm{Si}$ が溶解し て液,谪組成も変化するため，純 $\mathrm{A} 1$ ではこれらが原因とな って接触角が時間とともに変化する結果になると考兄られ る。これに対し Al-Ca 合金では界面反応が Caにより抑制 され，接䖪角の変化もほとんどない，

\section{IV. 結 言}

鋳造複合材料を製造する際の粒子分散促進元素である Ca の作用を研究するため, 純 Al および Al-Ca 合金と黒 鉛， $\mathrm{Al}_{2} \mathrm{O}_{3}$ および $\mathrm{SiO}_{2}$ 基盤との濡れ性を $973 \sim 1273 \mathrm{~K}$ の 温度で $3.6 \mathrm{ks}$ まで調査し, 以下の結果を得た。

(1) スポンジ Ti に水素を吸蔵させ，これを真空吸引し て再放出させることにより $0.5 \mathrm{kPa}$ 程度 (数 Torr) の減圧 水素䨌团気を作った。この中で $\mathrm{A} 1-\mathrm{Ca}$ 合 金液滴を固体基 盤上に押し出すことにより，酸化皮膜および Ca の蒸発の 影響を除去して静滴法により接触角を測定することが可能 であった.

（2）Caを 1〜2\%添加することにより，溶融 $\mathrm{A} 1$ と黒鉛， $\mathrm{Al}_{2} \mathrm{O}_{3}$ および $\mathrm{SiO}_{2}$ 基盤との濡れ性が向上した.

(3) $\mathrm{A} 1$ 抌よび A1-Ca 合金液滴と固体基盤との接触角は

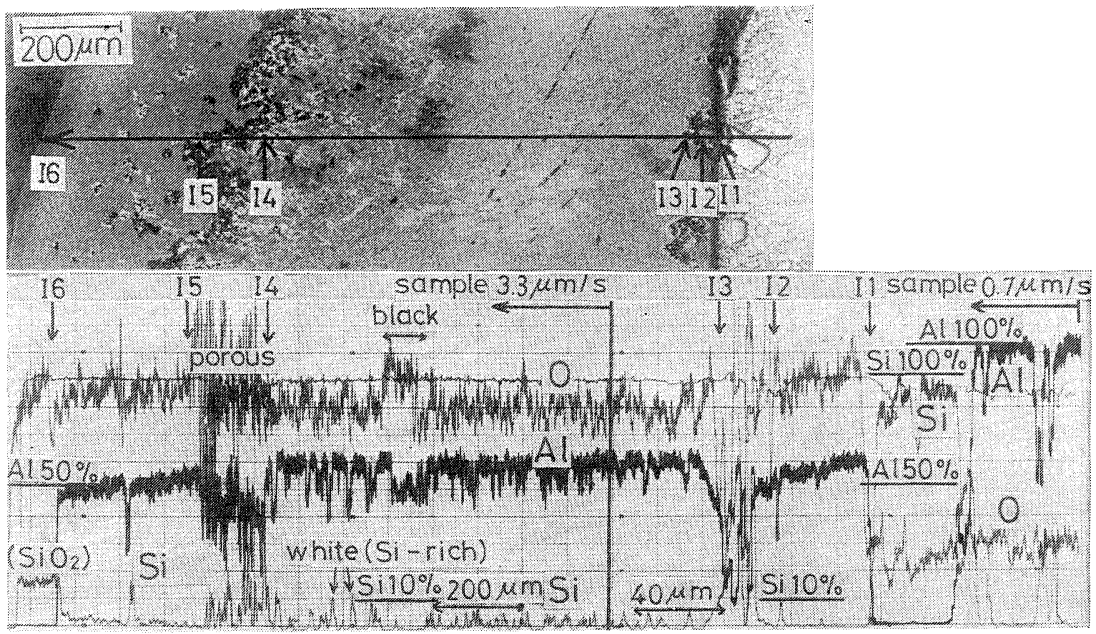

Fig.13 EPMA line-scanning profile across $\mathrm{Al} / \mathrm{SiO}_{2}$ interface. Specimen was held at $1173 \mathrm{~K}$ for $3.6 \mathrm{ks}$ prior to the analysis. 


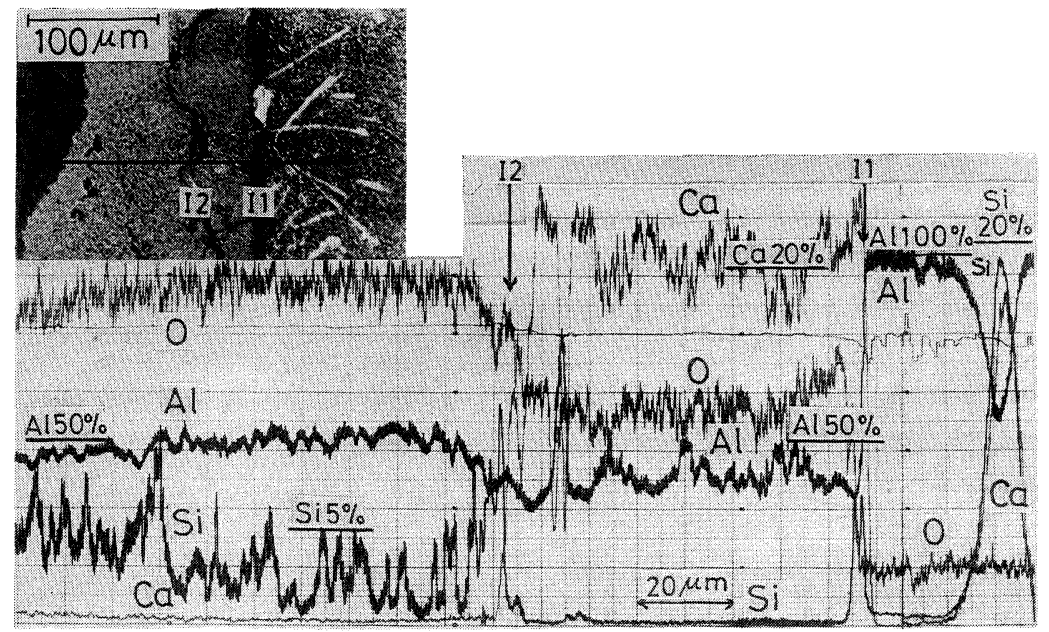

Fig. 14 EPMA line-scanning profi.e across $\mathrm{Al}-\mathrm{Ca} / \mathrm{SiO}_{2}$ interface. Specimen was held at $1173 \mathrm{~K}$ for $3.6 \mathrm{ks}$ prior to the analysis.

高温ほど低い傾向があるが，この傾向は黒鉛基盤では純 $\mathrm{Al}$ ，また $\mathrm{Al}_{2} \mathrm{O}_{3}$ および $\mathrm{SiO}_{2}$ 基盤では $\mathrm{Al}-\mathrm{Ca}$ 合金において 顕著であった。

(4) 黒鉛基盤では, Al および Al-Ca 合金とも $1123 \mathrm{~K}$ 以上での接触角が時間とともに連続的に減少し, その程度 は純 $\mathrm{Al}$ で，また高温ほど著しい。この原因は黒鉛と溶融 A1 との界面に拉ける反応物の生成であると考えられた。

(5) $\mathrm{Al}_{2} \mathrm{O}_{3}$ 基盤では，純 $\mathrm{Al}$ および $\mathrm{Al}-\mathrm{Ca}$ 合金とも 1173 $\mathrm{K}$ 以下での接触角の経時変化はほとんど認められなかっ た．A1-Ca 合金では $1073 \mathrm{~K}$ 以上で界面反応層が生成した が，これはぬれの進行には寄与していないと考えられた。

(6) $\mathrm{SiO}_{2}$ 基盤では, 純 $\mathrm{Al}$ の場合には $1073 \mathrm{~K}$ 以上で接 触角が時間とともに減少した。 これは $\mathrm{SiO}_{2}$ が溶融 $\mathrm{A} 1$ に より還元されて著しい界面反応層を生じ，また液滴中へ多 量の $\mathrm{Si}$ が溶解したためと考えられた。一方，A1-Ca 合金 では界面反応層の生長が純 $\mathrm{A} 1$ の場合より抑制され，接触 角の経時変化はほとんど認められなかった。

\section{文献}

（1）小原嗣朗：日本金属学会会報, 14(1975)，581.

(2) E.Fitzer and E.Ignatowitz: High TemperaturesHigh Pressures, 7 (1975), 299.
(3) N.Eustathopoulos, J.C.Joud, P.Desre and J.M. Hicter : J.Materials Science, 9(1974), 1233.

(4) C.R.Manning, Jr. and T.B.Gurganus : J.Am . Ceram. Soc., $52(1969), 115$.

（5）小原柌朗, 武藤範雄: 東京大学宇宙航空研究所報 告, $13(1977), 719$.

(6) K.Prabriputaloong and M.R.Piggott : Surface Science, 44 (1974), 585.

(7) J.A.Champion, B.J.Keene and J.M.Sillwood: J. Mater. Sci., 4 (1969), 39.

(8) J.J.Brennan and J.A.Pask : J.Am. Ceram. Soc., $51(1968), 569$.

(9) R.D.Carnahan, T.L.Johnson and C.H.Li : J. Am. Ceram. Soc., 41 (1958) , 343.

(10) W.M.Wolf, A.P.Levitt and J.Brown: Chem. Eng. Progr., 62(1966), 74.

（11）秋山 茂, 今川耕治, 長田純夫, 北原 晃, 上野 英俊 : 日本鋳物協会九州支部第 35 回講演大会概要, (1981), p.21.

(12) M. Hansen and K. Anderko : Constitution of Binary Alloys, (2nd Ed.), McGraw-Hill Book Co., New York, (1958) , p.800.

(13) 大蔵明光：鉄と鋼, 68 (1982)，902。

(14) M.Hansen and K. Anderko: Constitution of Binary Alloys, (2nd Ed.), McGraw-Hill Book Co., New York, (1958), p.75.

(15) 横田 勝, 野瀬正照, 高/由重, 三谷裕康：日本金 属学会誌, 44(1980), 770 .

(16) S.Newman : J.Colloid and Interface Science, 26 (1968), 209. 